\title{
Testicular Well Differentiated Neuroendocrine Tumor
}

National Cancer Institute

\section{Source}

National Cancer Institute. Testicular Well Differentiated Neuroendocrine Tumor. NCI

Thesaurus. Code C6360.

A rare well differentiated neuroendocrine tumor (carcinoid tumor) that arises from the testis. 